\title{
"Refugee!" The Adjustment of Jewish Refugees from Nazism to Canadian Life
}

The 1970s were years of political and social ferment in French Canada. At that time I was conducting a series of interviews with former refugees from Nazism, most of them Jews, many of them residents of Quebec. As Englishspeaking Quebecers these men were concerned, as were many Jews, with the rising tide of French-Canadian nationalism and its consequences. The possible resurgence of flagrant antisemitism was on everyone's mind. Indeed some of these men, now in their fifties and sixties, had already moved to Ontario, and others were contemplating relocation.

My questions seemed self-evident. After all they had been through under Nazism, was it not doubly hard for them to move yet again? Their answers surprised me. It was not difficult at all! Once a refugee, I was told, always a refugee. It was a lesson they had no need to learn twice. For forty years they had been mentally packed and ready. I had encountered the tenacity of the refugee mentality.

Forty-five years ago a group of over two thousand men and boys, German and Austrian refugees from Nazism, were shipped from temporary internment camps in Britain to prisoner of war camps in Canada. For the next three and a half years they remained prisoners or parolees in a country which did not welcome Jewish immigrants. By 1944 half of these men were released to live in Canada - the remainder returned to Britain through frustration, free will or force.

For those who stayed in Canada conditions varied. Students, sponsored by Canadians, fared well and quickly prospered. Others went to work on farms and in factories where they were sometimes exploited and their adjustment was more difficult. All entered Canadian life with the same stigma "refugee".

The peculiar circumstances which brought the interned refugees to Can- ada and the probationary nature of their release from the camps made them wary of fully entering Canadian life.

The only thing that was told to us ... is behave well and be sure that we don't make any trouble... otherwise we'd be returned immediately. This fear was with us all the time... So with that kind of attitude you don't mingle in politics, you don't join anything, you don't do anything wrong.

The interned refugees were hesitant to complain when exploited and were unfamiliar with means of redress. The Nazis had taught German and Austrian Jews that friends could quickly become enemies and so fear and suspicion marked the early years of their adjustment to Canada.

The unusual character of this group of refugees also contributed to their Canadianization. Many had been Jews only in accordance with Nazi racial definitions and they found it easier to lose the dual stigma of "Jewish refugee" through complete assimilation. However, most gravitated to the Jewish community where they discovered that their background gave them minority status.

Despite the fact that many of these refugees from Germany and Austria worked in companies dominated by Eastern European Jews, they mixed quite easily. The internment process had provided opportunities which most refugees never received and experiences which, many recall in retrospect, permanently altered their perspectives. Most of the internees had come from upper and middle class backgrounds. They now confronted manual labour jobs. If they worked with their hands, often for the first time, so, they soon learned, did the vast majority of the Canadian Jewish community.

What impressed me the most, coming to Canada, is the lack of the caste system. In Canada I learned very soon that the only thing that counts was money, more or less, to determine your status. Another thing that I admired very much and that I was not used to from Europe was that Jewish people were workers here. That means that it was not a shame here to be an electrician or a plumber or a glazier or whatever. . Well in my background you wouldn't dream of it. People would look down on you if you were in a trade. . .This impressed me very much in favour of this part of the world.

At ease in their jobs, most interned refugees were able to make friends with their co-workers. For many it was a whole new lifestyle. "It made me a much better person", recalled one internee.

All the experiences. Because I was rather spoiled. I came from a wealthy home and, terribly spoiled...

First of all, mixing with the working people and seeing their point of view. . They got a much bigger kick out of life than we did because they took it much easier... And I learned to relax a little, which I never did before.

Intra-Jewish tension, between German and Austrian refugees and the larger Eastern European community, receded with contact in the work-place but was never completely absent. Some refugees blamed neglect or indifference in the Jewish community for prolonging their internment. The few released refugees who put on airs of superiority to the largely working class Jewish community caused bitterness in return. In his book, The Street, Mordecai Richler recalls the first released interned refugees he encountered in Montreal.

I think we had conjured up a pic- 
ture of the refugees as penurious hassidim with packs on their backs. We were eager to be helpful, our gestures were large, but in return we expected more than a little gratitude. As it turned out, the refugees. . .were far more sophisticated and better educated than we were... They found our culture thin, the city provincial, and the Jews narrow... But what cut deepest, I suppose, was that the refugees spoke English better than many of us did, and, among themselves, had the effrontery to talk in the abhorred German language. Many of them also made it clear that Canada was no more than a frozen place to stop over until a U.S. visa was forthcoming. So for a while we real Canadians were hostile.

Yet these problems evaporated in the work-place.

This was a funny thing, and I gave up after a while to tell people. When I told people I came from Austria, they'd say "Oh, you're a landsmensch of mine. You come from Galicia too." And I tell him no, I came from Vienna. "You come from Austria. So you must come from the same part that I come from." So after a while, I'd say sure. I gave up. . . I learned how to speak Yiddish. With my German background it wasn't too hard. I got along very nicely.

For the majority of men who successfully adjusted expectations and made conscious efforts to adapt, life in Canada in the 1940s was full of promise.

These men, some as young as seventeen and some in their sixties, had to start their new lives from scratch. The survivors of the Holocaust who followed them to Canada would have similar experiences. No one was going to make it easy for them.

In my mind the injustice of the whole thing still rankles. After all, we were anti-Nazis. We were genuine refugees from German oppression. We lost our families to the Holocaust. We lost our chance for education in Germany. We lost all our possessions. I left Germany with the proverbial ten marks which were used up by the time I crossed Holland. And we had to start life anew in England, and due to the internment experience we had to start life anew in Canada again, penniless and without support. It has taken practically the whole of my youth and my formative years, I would say to about the age of thirty, before I could actually start to live again. . Somehow, between the cooperative efforts of the Nazi government and the British Home Office and the Canadian

Young as many of them were in years, the refugees released from internment into Canada were no longer youthful. Some were completely broken; most were anxious to pick up the pieces of their lives and many were fueled by an ambition which knew no bounds.

authorities, as far as they prolonged the experience of internment here, somehow our youth was stolen away from us. By the time we came out, mentally, we were already beginning to be middle-aged. We had gone through too much...It's a pity, but that's what happened. It's irreversible; crying about it makes no sense and I have never even talked about it until this very opportunity. Life goes on.

Young as many of them were in years, the refugees released from internment into Canada were no longer youthful. Some were completely broken; most were anxious to pick up the pieces of their lives and many were fueled by an ambition which knew no bounds. There was no longer time to waste. Bitterness, instilled by years of unjust treatment, had to be overcome. After years of uncertainty followed by years of incarceration, the interned refugees deserved time to adjust to Canadian life.

This was not to be. Many had prepared, as best they could, by gaining a fluency in English. Others were wary and unprepared. No one was exactly sure what to expect and experiences differed.
"I found adjustment relatively easy", recalled one ex-internee, "because I stayed in Germany until 1939. So my memories of Germany were not the best... I found the freedom in Canada and the relatively open society as rather worthwhile."

For another adjustment was difficult. "I came from a very small place in Germany... And being a free man and walking around in Montreal, it irritated me that everything was so fast - the traffic. And people were running only after money. Money meant everything. Money and nothing but money. It was shocking."

Indeed adjustment to Canadian life was easiest for two groups - the students and the orthodox Jews. The students found Canadian social contacts in school and through the help of their sponsors.

The orthodox melted easily into the religious community. Yet they, too, an internee explained, had problems.

It was always my impression that English, and perhaps French, was the vernacular of Canadian Jewry. To my astonishment I found out that the older and also middleaged Jews speak mostly Yiddish ... My limited English seems to be a great deal better than many of my Canadian friends'. They, in turn, cannot comprehend how a European Jew cannot speak Yiddish.

Integration into the Canadian Jewish world was one difficulty that all the Jewish refugees faced. Canadian Jewry, divided along organizational, language, and class lines, presented an unusual dilemma to the incoming refugees. The refugees were a group of well-educated and assimilated German and Austrian Jews. Some harboured old-world prejudices. And they were, with the exception of the students, entering a working class milieu dominated by Polish and Galician Jews. Some were told bluntly, "I want you to know that we don't like German Jews".

In return many refugees behaved arrogantly, which only served to further alienate them from the community. Until the war ended and the full extent of the Holocaust was known, feelings of alienation from fellow Jews played 
a significant part in the adjustment of these new immigrants.

Yet the overall experience of the refugees as they became integrated into the Jewish community was far from negative. For Germans who needed to learn Yiddish the task was not too difficult. Those truly interested in finding their place among the Canadian Jewish community found no real impediments.

There were certainly surprises. A young student, released to attend Queen's University, heard about a rabbi in Ottawa who had stolen a car, chased women and gambled.

I was so shocked. I was a very innocent young boy and I was so shocked that I wrote to my friends in Camp: "Canada is such a terrible country, even the rabbis are a bunch of crooks". That letter was intercepted by the Commandant ... So he called Mr. Samuel Bronfman and he said: "Look, we let these fellows come out and immigrate to Canada and look what they write about your community". So Mr. Bronfman called me on the carpet: "Listen, you'd better be cautious in what you write here about Canada".

The refugees found themselves entering a Jewish community which was as interested in helping them as it was in assuring they behaved. In Montreal and Toronto the Canadian Jewish Congress provided loans and clothing, free access to doctors and advice; homes were located, religious needs provided for and Jewish families encouraged to open their homes to the refugees. The help was appreciated. "I found the Jewish community an extremely warm community", explained one refugee fondly. "For the first time in my life the doors opened up to me and I felt extremely comfortable".

Nonetheless, the first years of Canadian life were difficult for some - more difficult, recalled one internee, than he expected.

I really found it a traumatic experience after internment camp coming to Toronto and being nobody all of a sudden. There's tremendous trauma attached to being a refugee. My parents were respected people in the commu- nity. I was always a top student in school. I usually had a whole circle of people around me... And here nobody knew me - "Refugee $^{\prime \prime}$ - very difficult to live with that kind of thing.

In the years that have passed since internment, none of the refugees have forgotten their experiences. It marked their lives and determined the progress of their adjustment to the Canadian and Jewish communities.

Some of the internees found comfort in retaining their internment camp friends. They had already lost much, but the comradery of fellow internees allowed them to share experiences that all felt. Every internee might ask: "Why was I protected? Who protected me? How was I chosen? How come the other ones all went to Dachau, Buchenwald and never came out? All my cousins are dead. They cleaned up all my friends. All my friends are dead." And so their fellow refugees became their anchor. "This was my family. These were the people I was closest to. These were the people I understood." For most, marriage, schools and jobs brought new contacts and eased adjustment.

Some who never overcame the despair of internment denied the experience, refusing to socialize with other refugees. "Every once in a while", a reluctant interviewee explained, "I speak to somebody about it and usually I don't sleep for three days, even now. So I'm very hesitant to talk about it. I never think about it. I have it in the back of my mind."

Others openly reflect on their internment experience, sometimes seeing it as part of the common adjustments all survivors of the Holocaust must endure. "Naturally you lost several years of your life", explained one internee. "My whole life didn't develop the way I wanted it to. But these are romantic dreams... You make things do." "I think of it every day of my life", explained another. "Till I die, I will never forget it. I can't."

With time, most interned refugees eased into their places in the Canadian community. For some there is a realization that the internment experience, scarring as it was, saved their lives and opened new horizons.
You feel, in one way, a wasted time - you lost two or three years - on the other hand you are happy to be saved by these circumstances. Millions of people lost their lives. So I regard it as a happy accident to come through the war like this ...The experience itself wasn't always pleasant... but this is what war is. It displaces people. And if you look around you just can thank your stars you're in a country like Canada.

Indeed many of the refugees succeeded in Canada and their achievements far exceeded anyone's expectations of them. For some this serves to magnify the irony of their internment and intensifies their pride in their achievements. According to several internees, internment and the resulting hardships has created its own motivation to succeed in all they do.

We all received a drive - to make up for the lost years we had as kids. The totally useless two years ...We had to make up fast, quick and get somewhere and try and recreate the type of life that we remembered as children. . . it's because we had nobody to rely on. They had to make it on their own ...We just couldn't afford to fail. We had to succeed... In my particular case every living minute was spent learning and working and producing, at the cost of my teens. I had no youth.

If you have no parents you are thrown on yourself. You can go two ways. One way, you give up. $\mathrm{Or}$ - I'm going to make something. I'm going to show them. Even though I may be a dirty Jew and a refugee... I'm just as good as everybody else.

Perhaps it is just this determination won through suffering, loss and forced immigration - that separates the refugee from other immigrants. For the refugee, the past is never reconciled and the future never certain.

Paula J. Draper was the historical consultant with the Toronto Holocaust Memorial and Education Centre. Her paper is based on her doctoral dissertation "The Accidental Immigrants: Canada and the Interned Refugees" (University of Toronto Department of Educational Theory, 1983). 


\section{Book Review}

\section{Michael R. Marrus}

The Unwanted:

European Refugees in

the Twentieth Century Toronto: Oxford University Press, 1985

Throughout history, mankind has migrated, whether from valley to valley or to a distant continent. At times, these population shifts may have affected only a relatively small portion of human society while on other occasions, particularly during the past century, migration has had an impact upon literally millions of people worldwide.

Human migration occurs for many reasons. One cause apparent in the majority of population movements can be attributed to a desire to acquire a higher standard of living and a more pleasing way of life. Indeed, economic factors have been a significant impetus in both compelling people to leave their traditional places of residence or drawing them towards what they frequently believe to be a "promised land".

As strong as the economic motives behind human migrations may be, widespread population upheavals can also be explained by even more basic factors. To avoid officially condoned persecution and threats to life and property, unexpectedly sizable numbers of persons have too frequently felt the need to flee involuntarily from their homelands. To a large extent, it is that portion of European society that has believed it necessary to escape these latter brutal conditions that is the focus of the recently published work under review.

The objective of this comprehensive study is to describe and examine involuntary population movements in Europe that have occurred primarily in the Twentieth Century. The author seeks in this work to point out the causes behind the many movements and addresses the issue of how attempts were made to cope with the many hundreds of thousands of "unwanted" persons by governments and inter-governmental organizations. In each of the situations or cases described, persons in flight sought an environment or haven free from man made oppression and horror where a more fulfilling way of life could be at least attempted.

In general, the involuntary population movements in Europe discussed in this study resulted from one or a combination of the following factors; rampant, intolerant nationalism, highly developed forms of persecution, and war or the anticipation of imminent war.

The number of involuntary population movements described by the author in substantial detail is almost overwhelming to the casual reader. The effect of the continuous recounting of so many instances of man's inhumanity to man is almost to numb the reader to the enormous tragedy that repeated itself again and again in Europe just in the years between the turn of the century and the end of World War II. A fragmentary list of the situations described would include Jews in Eastern and Central Europe, numerous eruptions in the Balkans, the plight of the Armenians, escapees from revolutionary Russia, persons uprooted as a result of the demise of the AustroHungarian Empire, and the better known cases involving fascist Italy, Nazi Germany and Franco's Spain.

To compile this book, the author carried out exceedingly thorough research in a number of countries using a large selection of archival holdings. This finished product, a monument to diligent and industrious investigation, will be of interest to scholars as well as to informed observers of European affairs in this century.

This seemingly endless chronology of humanity, compelled to be on the move, tends at times to become rather dower and gloomy. On occasion, however, the author provides some welcome relief from the succession of tragedies by describing almost anecdotally the characteristics of some of the persons who were uprooted. The account of a former Russian aristocrat, then in his mid seventies, surrendering his small group of anti-communist supporters to the Western occupying armies in Germany in 1945 is almost delightful.

This ambitious study has other attributes. It throws considerable new light upon one or two of the attempts that ended successfully in saving at least a few European Jews from the Nazis. Similarly, significant information regarding the forced repatriation of Soviet nationals by Western governments following the end of hostilities in Europe is also provided. Moreover, the obvious frustrations encountered during the mid 1930 s by James McDonald, the short lived League of Nations High Commissioner for Refugees Coming from Germany, are examined and enumerated.

Despite the obvious worth of this ably written book, there are some noteworthy shortcomings. Without wishing to dwell unduly upon the issue of refugee definitions, the fact remains that the author unfortunately uses the term "refugee" to cover virtually all mass population movements examined in this study. While admittedly the present UNHCR definition is certainly somewhat narrow and restrictive, it does at least strive to provide a little precision to the term. The sweeping use of the term refugee used in this work detracts from efforts that are being made to clarify the meaning. The word "unwanted" that is used in the book title is certainly a preferable term in the context of the population movements studied here.

The almost endless series of involuntary population movements discussed in the book have been briefly commented upon earlier. The reader would be significantly assisted in appreciating the importance of these migrations if they were grouped together more effectively in some classificatory scheme. Now, the reader is left with the impression that the primary reason any of the forced movements appears in the book rests with the fact that they took place in Europe in this century. It would be preferable to classify the movements by cause or by the impact felt by the reluctant receiving governments. The absence of such a set of classifications is disappointing, indeed.

As comprehensive as this work is in the descriptive sense, it suffers at times from less emphasis upon an analysis or explanation of how and why certain events occurred. For example, while the text amply suggests that strenuous diplomatic negotiations surrounded many of the efforts to resolve problems 
facing the uprooted nationals of many countries, seldom is there a satisfactory focus upon what must have been intriguing intergovernmental deliberations. This is particularly the case with respect to population movements in the Balkans and involving Greece and Turkey in the post World War I era. Some more substantial attention to the negotiating postures of the affected governments would have added a valuable dimension to this study.

These and any other remarks of a similar vein that might be made really only skirt the more important problem associated with this book. Without doubt, the major disappointment arises from the absence of an explicit, conceptual or analytical framework in which to arrange and order the mountains of data so painstakingly gathered by the author. While a simple chronological approach to the various movements is adopted, something a little more helpful in terms of arranging information in patterns seems most desirable. One encounters one appalling human tragedy after another with little apparent attempt to deliniate or distinguish patterns of causes. Many of the criticisms expressed above would, in fact, disappear if an appropriate conceptual framework or scheme had been chosen. As it is, the book, while demonstrating able research, does lose at least a little of its potential scholarly impact.

It is not the intent of this review to conclude on a negative note. It needs to be pointed out that the epilogue constitutes one of the most readable and effective portions of the entire book. This succinct section traces intergovernmental activity in Europe in the post World War II era aimed at resolving the refugee and displaced persons situations on that continent. The discussion is both clear and cogent, containing just the essential details. While the author must be warmly congratulated for putting together such a comprehensive, detailed picture of involuntary population movements in Europe, the fact remains that the volume is a little less that it otherwise might have been, owing to the reasons set out above.

Gerald E. Dirks is Associate Professor in the Department of Politics at Brock University and author of Canada's Refugee Policy: Indifference or Opportunism?

\section{Annual Report to Parliament on Future Immigration Levels 1985}

The Annual Report to Parliament on Future Immigration Levels was tabled on October 31 by Walter McLean, Minister of State for Immigration. In his statement to the House, the Minister said: "Canada will increase its growth of government-assisted refugees in 1986 by 1,000 , from 11,000 to 12,000 , at a time when many refugee-receiving nations are becoming more restrictive.
These refugees will be aided by an additional provision of $\$ 3.0$ million to the Adjustment Assistance Programme. An additional $\$ 750,000$ is being provided to agencies to provide direct aid to refugees and other needy immigrants. In total, the 1986 plan allows for some 20,000-23,000 humanitarian landings, the second largest plan in the world next to the United States."

\begin{tabular}{|l|r|r|c|}
\hline \multicolumn{4}{|c|}{ GOVERNMENT-ASSISTED REFUGEE ALLOCATIONS, 1985-1986 } \\
\hline & 1985 & 1986 & Change \\
\hline Eastern Europe & 2,200 & 3,100 & +900 \\
Southeast Asia & 3,700 & 3,200 & -500 \\
Latin America & 3,000 & 3,200 & +200 \\
Africa & 1,000 & 1,000 & - \\
The Middle East & 800 & 900 & +100 \\
Other World Areas & 200 & 300 & +100 \\
Funded Management Reserve & 100 & 300 & +200 \\
\hline TOTAL & 11,000 & 12,000 & $+1,000$ \\
\hline
\end{tabular}

\section{News Digest}

- Olof Rydbeck, CommissionerGeneral of the United Nations Relief and Works Agency for Palestine Refugees (UNRWA) since 1979, retired on 31 October after a long and distinguished career, and has been replaced by Giorgio Giacomelli of Italy. Giacomelli has been Director-General of the Department of Co-operation and Development in the Italian Foreign Ministry since 1981.

- The Refugee Studies Programme at Queen Elizabeth House began in 1982. It brings together host government officials, scholars and professionals with a wide range of persons with specialized knowledge in relevant fields. Queen Elizabeth House offers access to Oxford University's unique library and archival resources, and has long experience in mounting training courses for overseas personnel in administrative and foreign service, and in providing research facilities for Visiting Fellows. The Refugee Studies Programme emphasizes refugee participation, the strengthening of host country institu- tions and talents of personnel, the need for independent research and evaluation, training and development. Refugee Issues, a quarterly series of working papers, is published in co-operation with the British Refugee Council. Applications and enquiries should be addressed to Dr. B.E. Harrell-Bond, Programme Co-ordinator, Refugee Studies Programme, Queen Elizabeth House, 21 St. Giles, Oxford 0X1 3LA U.K.

- The annual subscription rate for Refugee Reports has ben reduced to $\$ 28.00$. Multiple orders are available at $\$ 20.00$ each. Refugee Reports is a 16-page monthly devoted entirely to refugee issues. It covers national and local programmes to meet refugees' needs, international refugee situations, U.S. legislation, regulations, and litigation affecting refugees, research, statistics, and resources. Subscribers also receive the U.S. Committee for Refugees' World Refugee Survey and its Issue Papers series. To subscribe, send a cheque with your name, affiliation, if appropriate, and address to: Refugee Reports Subscriptions, Sunbelt Fulfillment Services, P.O. Box 41094, Nashville, TN 37204, U.S.A. 


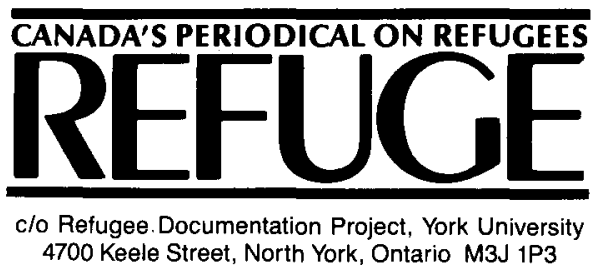

Postage Paid in Toronto

Second Class Mail Registration No. 5512

Return Postage Guaranteed

\section{New \\ Publications}

* Baker, Reginald P. and North, David S. The 1975 Refugees: Their First Five Years in America (Washington, D.C.: New Transcentury Foundation, 1984)

* de Neef, C.E.J., and de Ruiter, S. J. Sexual Violence against Women Refugees (Amsterdam: Ministry of Social Affairs and Labour, June 1984)

* North, David S. Alien Legalization and Naturalization: What the United States Can Learn from Down Under. (Washington, D.C.: New Transcentury Foundation, 1984)

* North, David S. Refugee Earnings and Utilization of Financial Assistance Programs. (Washington, D.C.: New Transcentury Foundation, 1984)

* Proceedings of the International Seminar on Refugee Women in Soesterberg, the Netherlands, 22-24 May 1985. (Amsterdam: Dutch Refugee Association, 1985)

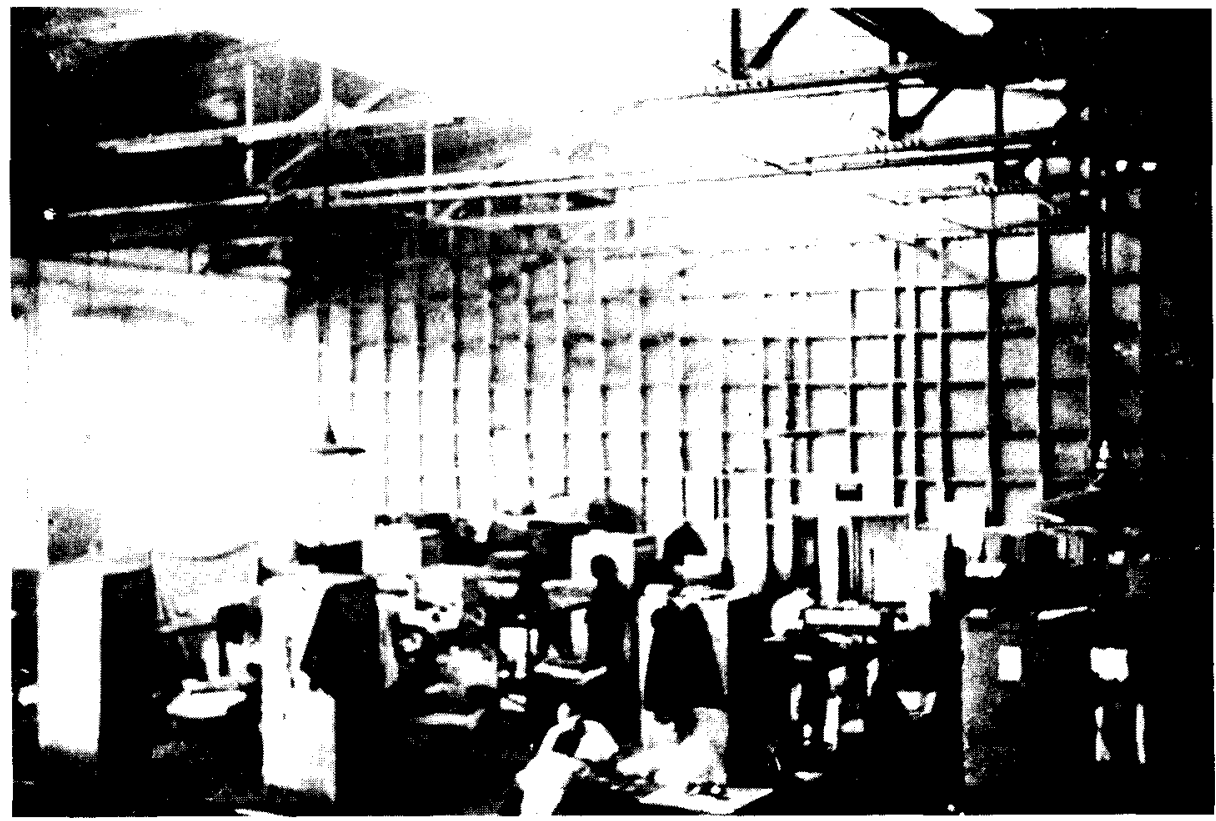

Living quarters, Camp N, Sherbrooke, Quebec. Shot taken with an illegal pinhole camera. (Photo by Marcell Seidler).

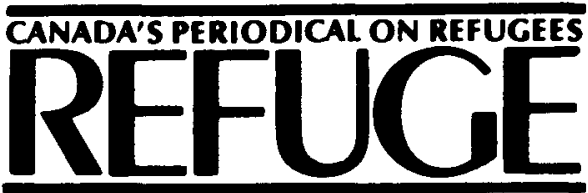

c/o Refugee Documentation Project, York University 4700 Keele Street, North York, Ontario M3J 1P3

I wish to become a supporter of the Refugee Documentation Project. I understand I will receive Refuge free of charge for one year, as well as information on the research activities of the RDP. My check for $\$ 20$ (or ) made payable to the Refugee Documentation Project is enclosed.

Name Organization

Address

City Province or State

Country Postal Code 